\title{
The Holocaust in the British imagination: the official mind and beyond, 1945 to the present
}

\author{
Tony Kushner \\ Faculty of Humanities, Parkes Institute, University of Southampton, Southampton, UK
}

\begin{abstract}
This article traces how the Holocaust has been responded to at a political level in Britain from 1945 to the present. It includes key moments such as the liberation of the camps in 1945, the Eichmann Trial in 1961, compensation schemes from the mid1960s, and more recent forms of pedagogic and memorialization issues since the 1990s, ending with the Prime Minister's Holocaust Commission (2014 onwards). While the focus is on the official sphere, attention is given throughout to wider cultural and social trends and contexts for the whole period. It emphasizes the contrasting meanings and politics associated with British confrontations with the Holocaust in the postwar era, using for the more recent period especially the 2016 UCL survey What Do Students Know and Understand about the Holocaust?
\end{abstract}

\section{KEYWORDS}

liberation of Belsen;

Eichmann Trial;

compensation;

memorialization; Holocaust education; Holocaust

Commission

Exciting news, trend watchers! The look of the season is ... Adolf Hitler. Yes, as you may have heard, Adolf is having quite a moment these days, getting trotted out by British politicians like a new charity ribbon on a lapel. This IT boy is so zeitgeist, I'm amazed I didn't spot him on the red carpet at the Met Ball: here's Alexa Chung, so darling in vintage Yves Saint Laurent; there's Beyonce looking very on trend in Givenchy; and oh look, there's Adolf, really owning that Waffen-SS look. Work it, Adolf. ${ }^{1}$

Hadley Freeman is the fashion editor of the Guardian. If this haute couture fantasy appears tasteless and puerile, there is a serious argument behind her satire. Chronology and anniversaries will underpin this article and Freeman is astutely aware from her own family background that different narratives of the Second World War can be, and often are, sources of exclusion, friction, and distortion. In this case, she was responding to two particularly crass interventions by leading British politicians evoking the Nazi era.

In May 2016, when debate about the referendum concerning Britain exiting or remaining in the European Union was becoming increasingly led by the politics of fear and hyperbole, Boris Johnson added to the general atmosphere of paranoia. As the most prominent politician in the "Leave" campaign, he suggested that the attempt at political union in the EU had also been the aim of Hitler and, he warned, "it ends tragically." 2 The former mayor of London's crude intervention had a particularly negative resonance for Hadley Freeman: "Johnson activated the Hitler button the day after the 75th anniversary of the 
day my great-uncle, Jakob Glass, was, along with 5,000 other Jews, arrested in Paris, after which he was sent to Auschwitz, where he was killed."3

Johnson was not the first Conservative to make the claim that the European Union was completing the vision of the Nazis. In 1990, the Conservative Trade and Industry Secretary, Nicholas Ridley, told the Spectator that the idea of European monetary union was "a German racket designed to take over the whole of Europe ... I'm not against giving up sovereignty in principle, but not to this lot. You might just as well give it to Adolf Hitler." ${ }^{4}$ But Johnson's more recent comments need to be juxtaposed with those of another former mayor of London, Ken Livingstone, who had also namechecked Hitler a fortnight earlier - though somewhat more idiosyncratically.

Livingstone shares the populism of Johnson but not his politics; he is on the left of the Labour Party. At the climax of the 2016 London mayoral contest, Livingstone intervened in the increasingly tense controversy concerning allegations of Labour antisemitism relating to the politics of the Middle East. Livingstone claimed that the recent suspension of Bradford Labour MP Naz Shah was because of a "well-orchestrated campaign by the

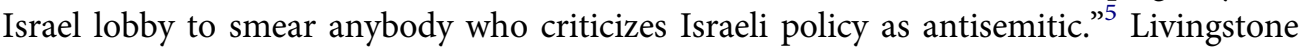
added that he had "to put up with 35 years of this" and then evoked "history" to bizarrely illustrate the absence of prejudice behind his anti-Zionism:

Let's remember when Hitler won his election in 1932 his policy then was that Jews should be moved to Israel. He was supporting Zionism before he went mad and ended up killing six million Jews. ${ }^{6}$

Livingstone is keen on reading about history - a hobby that has got him into more trouble than his passion for breeding and keeping newts. And rather than apologize for his outburst, he vindicated his "knowledge" on Hitler in this instance with reference to the longdiscredited polemic, Zionism in the Age of the Dictators (1983), by American Trotskyite Lenni Brenner. ${ }^{7}$

Hadley Freeman notes of Boris Johnson that " $[t]$ here is no way he actually believes the EU is Hitler's ambition realized ... For $£ 37,000$ a year, I assume Eton teaches the difference between European unity and European domination." ${ }^{\text {A }}$ A few weeks earlier, the Guardian columnist quipped that she was very much looking forward to the publication,

History: According to Ken! in which he will explain, alongside Hitler's enthusiasm for a Jewish homeland, how Jack the Ripper was trying to get women out of prostitution ... [and] slave traders were simply taking Africans on package holidays so they could see the world. ${ }^{9}$

There are some dubious assumptions lurking in Freeman's comparison - that the privately educated Johnson knows exactly what he is doing in manipulating public prejudice while the autodidact Livingstone cannot tell the difference between historical fact and fiction. It remains that Johnson's biography of Winston Churchill (2014) was dismissed by scholars for its inaccuracies and widely perceived as disguised autobiography from a man with huge ambitions for political power. ${ }^{10}$ What is significant in the context of this article is how both former mayors of London utilize the past, especially that of the Nazi era and Britain's relationship to it: they have constructed, mythologized, and instrumentalized it with little regard either to detailed, critical, historical research or the impact of formal pedagogy towards that end. Ridley, too, was unequivocal in utilizing his understanding of history. 
Asked if his Germanophobic views were colored by the memory of the Second World War, he responded:

Jolly good thing too. About time somebody said that. It was pretty nasty. Only two months ago I was in Auschwitz, Poland. Next week I'm in Czechoslovakia. You ask them what they think about the second world war. It's useful to remember. ${ }^{11}$

What do these disturbing political performances of the late twentieth and early twentyfirst century tell us about Holocaust commemoration and education in Britain since 1945? Is it revealing only of eccentric, publicity-seeking, and maverick politicians or of wider attitudes? What follows is an episodic overview choosing key political or diplomatic moments - though keeping in mind throughout that their chronological precision should not disguise the importance of longer-term cultural and social trends. The complexity that emerges is heightened by the different and often competing strands of memory work that are present at any one point in time, making generalizations reductive and potentially dangerous. For example, if History: According to Ken! or, for that matter, According to Boris and Nicholas! paint a depressing picture of ignorance and distortion if they are regarded as barometers of British understanding of the Third Reich and/or the Holocaust, it is contemporaneous with a greater sensitivity and self-reflexivity over confronting these subjects as reflected in the UCL's Centre for Holocaust Education's What Do Students Know and Understand about the Holocaust? (2016) and this volume in response to it. Indeed, this extensive survey will be referenced throughout the overview that follows. ${ }^{12}$

While the egocentric nature of both London politicians has to be kept in mind (and that of Ridley earlier), their crude and immature Hitler-centric approach remains, and the assumptions behind it are not isolated. It reflects, for example, a much wider (mis)understanding among secondary school children, especially and appropriately among the youngest aged from 11 to 14 . According to the UCL report, "More than half ... appeared to believe the Holocaust was solely attributable to Adolf Hitler." ${ }^{\prime 3}$ Indeed, the findings of the 2016 report will be related to other moments and events related in this article as a way of assessing how classroom knowledge relates to wider tendencies.

\section{II}

The liberation of the western concentration camps, and especially Bergen-Belsen, will be a recurring reference point throughout this study of the relationship between Britain and the

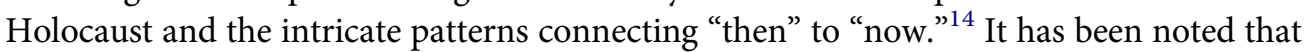
in British culture, "Bergen-Belsen occupies a distinct position in the remembrance of the Second World War." ${ }^{15}$ The meanings associated with Belsen, however, have been far from static and have been constantly contested. ${ }^{16}$ For the British state, it was important in the last days of the conflict not only to verify what had been discovered when the British and American armies liberated concentration camps including Belsen, Dachau, and Buchenwald, but also to ensure that the "right" message was conveyed to the public from these traumatizing disclosures.

On 19 April 1945, General Eisenhower invited a delegation of British MPs to go to Buchenwald, which only days earlier had been liberated by the American army. ${ }^{17}$ The selection of these MPs was careful, with prominence given to what Churchill called the "unbelievers" and for whom, he noted in the House of Commons, "it might do a lot of 
good." 18 The aim of the delegation was "to test the accuracy of the reports already published," but the visit and the subsequent White Paper - written rapidly and published by the end of April 1945 - was also to highlight what the Western Allies had been fighting against. ${ }^{19}$

Eisenhower, when informing his head of Joint Chiefs of Staff of his intention to bring British individuals to "witness ... evidence of atrocity," wanted to leave "no doubt in their minds about the normal practices of the Germans in these camps." ${ }^{20}$ The emphasis in the Buchenwald Camp White Paper was likewise to ensure belief and to present it as a crime of the German people as a collectivity rather than that simply of a Nazi elite. This was also the message of the British Ministry of Information documentary film German Concentration Camps Factual Survey, assembled in early summer 1945 (its earlier working title was even more emphatic: German Atrocity Film). As with other contemporary reportage, there was a tendency in this film to downplay the Jewishness of the victims. This was true even in relation to representation of Belsen, where the large majority of the dead, dying, and surviving were Jewish. It reflected an unease that the viewer, listener, or reader, whether in Britain or Germany, would be less sympathetic and less likely to acknowledge the veracity of the reports if Jews were highlighted as the principle victims of the Nazi regime. ${ }^{21}$

In America, literary critic Susan Sontag relates seeing images from Belsen and Dachau in a Santa Monica bookstore in 1945:

Nothing I have seen ... ever cut me as sharply, deeply, instantaneously. Indeed, it seems plausible to me to divide my life into two parts, before I saw those photographs (I was twelve) and after, though it was several years before I understood fully what they were about. $^{22}$

In Britain, too, ordinary people, especially the young, were deeply affected, especially by the visual material from the liberation of Belsen in April 1945. The writer Alan Sillitoe was, in the words of medieval historian Colin Richmond, "one of the many" who remembers exactly where and when he saw the Belsen images. ${ }^{23}$ Then, the young Sillitoe and his mother consumed the liberation material in the way the government had intended:

Coming home from work one evening [in Nottingham], my mother, before bringing my food, opened the Daily Mirror to show a double page spread of photographs of Belsen. She leaned over my shoulder, and said: "Just look what the rotten Germans have done to people."

Yet Sillitoe adds: "Looking at those pictures, I did not take in at that time that the heaps of bodies, and the survivors, were Jews." That understanding would happen later and would be part of what he called "Jewish influences on my writing." 24

Fellow writer Frederic Raphael, in the immediate postwar years, also experienced the universalizing tendencies in British confrontations with Belsen, but with the impulse being the reverse of the empathy expressed by the Sillitoe household. In his public school, Raphael was known as "Belsen" - recollecting that this moniker resulted not from his fellow pupils' antisemitism (though he did suffer from it) but because he was markedly thin. It was done, Raphael was later convinced, "without any thought of Hitler's real aim." 25

The research of the social anthropological organization Mass-Observation suggests that the images from the camps, especially of Belsen, created an intense emotional response in 
Britain. The focus, however, as with the Sillitoes, was on the motives of the perpetrators rather than the impact on the victims. The Mass-Observers pondered whether this was a peculiarly German/Nazi crime or one about the nature of mankind more generally. The dominant response was typified by an office worker who reported, "Even the most confirmed sceptics are shaken by these pictures of Belsen camp and agree that the Germans are a bad lot." 26 There were those who were suspicious of what they saw as a government-inspired anti-German hate campaign, especially on the left, but even they were in no doubt about the reality of what had happened, only the interpretation of it. In what was an unusually nuanced response, one Observer recognized both the universality of the crime and those who were especially singled out as victims:

They say it's the fault of the German people [yet would] the same have happened here, I wonder, if we'd had the same government? I've heard some violent anti-semitic talk which makes me think it would. I feel it's the fault of humanity at large, not the Germans in particular. $^{27}$

Sontag was not alone in the Anglo-American world in dividing her life before and after confronting the liberation images. In rural Cheshire, Alan Garner, later to become one of (if not the) most important writers in postwar Britain, recalled in the 1980s how it confirmed to him as a young boy the true nature of the world:

The Belsen films were shown at our cinema. Although children were forbidden entry, we had always known the free way in. I saw the film four times. The not-dead corpse in the black skull-cap ... grinning at the camera that had come too late, the bulldozer ploughing its graceful hideous choreography into the mass grave.

Although officially too young, Garner had no doubt about the decision to illicitly watch the film: "It was right for us to see this ... Belsen made sense. At the age of ten, I realised what all the fuss had been about." Within minutes, he recalls, "I was violently wise." ${ }^{28}$ And reflecting on the energy of violence, whether interpreted as creatively good or destructively bad, has been at the heart of Garner's powerful, place-related work from the 1950s onwards. $^{29}$

Belsen undoubtedly made a difference in 1945 and there were British readings of Belsen, if some time after the spring, which did link it directly to the Jewishness of the victims. Again, however, they articulated utterly contrary perspectives. In terms of sympathy, it was most clearly expressed with regard to the child survivors of the Holocaust. In a privately funded scheme, eventually over 700 children were brought to Britain to recuperate. They had been in a variety of ghettoes, slave labor and concentration camps though few had been in Belsen itself. But in the national, Jewish, and local press they were labeled as the "Children from Belsen." 30 Their orphan status added further to their vulnerability and victimhood. ${ }^{31}$

One of the principle carers for the children was Dr Oscar Friedmann, a psychologist and himself an earlier refugee from Nazism. He noted perceptively with regard to British understanding of Nazi atrocities in the immediate postwar period, in an interview with the journalist Mollie Panter-Downes published by the New Yorker, "You know it's funny, the English press has called these children who have come over here Belsen children, but many have never been to that camp. Belsen and Buchenwald have taken all the limelight, but there were others far worse, far more horrible, which no one seems to 
know about. Many of our boys have been in four or five camps, and if you ask them, they say Treblinka, in Poland, was the worst." 32

It is perhaps an indication of the powerful resonance of the western concentration camps liberated by the British and American forces that Friedmann himself replicated this distortion. In the same interview, he highlighted how the children's collective lack of hope was "perhaps the worst thing Belsen and Buchenwald [has] done to [them]."33 In this discussion of camps, it is significant that Auschwitz was not mentioned, a contrast to its use as a metonym for the Holocaust from the latter part of the twentieth century onwards.

In this respect, it is revealing that the Centre for Holocaust Education's 2016 report highlights that across all age groups, 71 per cent associated Auschwitz with the Holocaust, whereas that figure was 15 per cent for Treblinka and the same for Belsen. ${ }^{34}$ It suggests a more nuanced, less British liberation-centered understanding of the "Final Solution" with Auschwitz more prominent than Belsen, but also the limitations of knowledge and understanding. Both then and now only one camp was/is given wide recognition. It reflects thus continuity and change and the inability to comprehend the complexity of the camp structure (and mass murder outside it) beyond one potentially distorting example.

But returning to the immediate postwar era, for many in Britain, Belsen evoked anger and a desire to help the survivors, including adults as well as children. An editorial in People in October 1945 pointed to the "Mockery of Belsen" - "a long-drawn-out trial" on the one hand, while the surviving Jews "plead in vain for sanctuary" on the other. It argued that there were relatives in the United States and Britain who "would guarantee their future" yet "Washington and Whitehall hold up their landing permits." 35

There was no consensus in the corridors of the latter about what to do about such requests to grant asylum to Britain for Belsen survivors. Public and parliamentary pressure pushed for action but a senior Home Office official was concerned about the numbers that might then be involved: "The inclusion of 'in-laws' would open the floodgates very substantially." 36 The slowness and restrictive nature of what would become the Distressed Relatives Scheme infuriated one former British soldier, T.H. Tilling, who had just been demobbed having commanded a team investigating war crimes. Exasperated, Tilling, who had returned to being a lawyer in the UK, wrote:

For six months in Germany I had my HQ at Belsen - perhaps you've heard of it! There are still about one or two thousand of the wretched people whom we liberated from the Camp who, for one reason or another, cannot get to Palestine. They are almost all young Jews and Jewesses of about 18-35 years of age who have lost their parents in the Gas Chambers of Auschwitz and other Concentration Camps. ${ }^{37}$

Tilling's understanding of the situation they were in and his criticism of the British government was highlighted as he continued:

They have, of course, been through hell, and now have absolutely no hope for the future and no knowledge of what their "liberators" intend doing with them.

He was at pains to stress how he had met these young adults and gained their confidence. It is revealing of the antisemitic tensions of the time, however, that he then defensively explained his interest: "Their plight has moved me most profoundly - I am not a Jew, neither have I anything to gain personally if I'm successful in helping them."38 
Tilling clearly was not without influence and connections, and he persuaded Captain Max Aitken (later Lord Beaverbrook) to run a leader and a story in the Sunday Express on the Jewish Belsen survivors in January 1946. ${ }^{39}$ Following this, "Thousands of people apparently wrote to the Sunday Express offering to take them." The Home Office had considered the possibility but taken no action. Tilling made no excuse for his anger over this refusal:

My feelings - which are very strong indeed - are that these people left alive who have suffered the full horror of the Nazi bestiality against which we fought, and there they are, still at Belsen, and apparently forgotten by us - literally eating their souls out because the future holds nothing for them. We ought to help them and now. ${ }^{40}$

Although some were more sympathetic, the dominant Home Office response was unequivocal: "There can for the present be no question of extending the eligible categories of the scheme for the admission of distressed relatives." ${ }^{11}$

If there were thus many in Britain who were motivated by the impact of the Belsen disclosures to demand that their government allow more Jewish survivors to come to the country, others took different messages from the horror. They reflected on the Jewishness of its victims, but in a totally negative manner. On 19 August 1946 in a British army camp in Warwickshire, notorious for its ill discipline, Mark Feld, a Jewish soldier, was asleep and struck a "fatal blow to the head with a truncheon" by Patrick Francis Lyons of the camp's military police. After a night's drinking, Lyons had boasted to a friend that he was going to "do Feld up" because he believed him to be a bad soldier - in fact he was a "tough Jew" who was unwilling to be cowed by the abuses taking place in the camp. According to Lyons, however, Feld "would fit only one place and that was Belsen." Remarkably, Lyons was found guilty only of manslaughter and given 10 years' penal servitude. ${ }^{42}$ The biographer of Feld's nephew, the "twentieth century superstar," Marc Bolan (previously Feld), sardonically notes that Private Mark Feld 14709755, a Jew who didn't need to go to Belsen to meet a tragic end, received two posthumous tributes: the Under-Secretary of State for War belatedly sent a service medal to his mother Bessie Feld; his elder brother Simeon named his second son in his memory. ${ }^{43}$

\section{III}

The "manslaughter" (that is, murder) of Mark Feld took place just 16 months after Belsen's liberation. In January 2015, in a very different context, and marking 70 years since the Soviet army's liberation of Auschwitz, David Cameron announced the findings of the Prime Minister's Holocaust Commission Report, Britain's Promise to Remember. ${ }^{4}$ A total of $£ 50$ million of taxpayers' money, to be matched by $£ 50$ million of private (essentially Jewish) funding, was to be put into a new national memorial to the Holocaust and a learning center. Considering the sums involved and the context of austerity cuts, especially to the welfare budget, and the struggle of British Jewry to maintain its wide-ranging organizational structure at home and support of Jewish life abroad, it is remarkable how little negative public comment was made about this initiative and the proposals coming out of it.

The very lack of controversy gives support for those who regarded the initiative as a "vanity" project for David Cameron and his close supporters - here was a way of 
establishing a "legacy" of compassion, of doing "right." Cameron, it could be argued, was "performing" his credentials as a "liberal," metrosexual European to a Jewish and nonJewish audience at home and abroad. It was aimed as a powerful gesture after attending the commemoration in Auschwitz in January 2015 which attracted global media interest. The unstable nature, however, of the tolerance that Cameron was projecting on himself and his government was to be exposed in the months that followed. In July 2015, the then Prime Minister, prompted into action by the populist right-wing press (whose xenophobia has been increasingly informed by a heavy dose of racism), referred on national news to "a swarm of people coming across the Mediterranean, seeking a better life, wanting to come to Britain." The acting leader of the Labour Party warned Cameron that he should "remember he is talking about people and not insects." 45 There was a bitter irony that such racialist populism came to haunt Cameron, as it was one of the major reasons for the slim majority that voted a year later to leave the European Union. If Cameron is worried about how "history" will deal with him, it is for this rupture and his failed campaign to "remain," rather than his Holocaust Commission, that Cameron's legacy will be remembered.

The Holocaust Commission was prompted also by the awareness that the survivor generation was fast disappearing (itself a reflection of the respect they have belatedly received) and something needed to be done to counter that impending loss. Yet analyzed soberly rather than emotionally - the ambitions of the Prime Minister's Holocaust Commission only partially met a real need. While two decades earlier Britain was behind internationally in forms of memorialization and pedagogy, this cannot be said of 2015. With a series of Holocaust museums and exhibitions, a saturation point reached in interviewing survivors in oral and video projects, artistic and literary engagement, and widespread (if, as the UCL survey highlighted, uneven) teaching, only with respect to a prominent national monument could there be regarded a lacuna in comparison with the rest of Europe or North America. That there has been only muted internal or external criticism highlights how Holocaust commemoration is deemed to be, per se, a good thing. To suggest otherwise is to go beyond acceptable political discourse.

As this article has already highlighted, memory of the Holocaust in Britain after 1945 developed in a complex and uneven pattern (including outright hostility to its recognition). The almost unanimously positive reception of this Commission in 2015 suggests, however, that in the second decade of the twenty-first century, the Holocaust has truly "come home" - though how "home" is constructed remains contested, as will continue to be highlighted here.

The work of the Commission, according to Chief Rabbi Ephraim Mirvis, "was a sacred duty to the memory of both victims and survivors of the Holocaust." 46 Indeed, the first paragraph from the Executive Summary Report echoes and amplifies the title of the report: "Ensuring that the memory and the lessons of the Holocaust are never forgotten lies at the heart of Britain's values as a nation." It begins by justifying that statement:

Seventy years ago, the world recoiled in horror as Allied forces liberated Nazi concentration camps and exposed the true scale and industrial evil of the darkest hour of humanity. Families in Britain listened with revulsion to Richard Dimbleby's harrowing description of starving prisoners and 10,000 heaped corpses encountered by British troops as they liberated the camp at Bergen-Belsen. ${ }^{47}$ 
The reassuring narrative presented does not end there: "In commemorating the Holocaust, Britain remembers the way it proudly stood up to Hitler and provided a home to tens of thousands of survivors and refugees, including almost 10,000 children who came on the Kindertransports." 48 There are caveats and nuances to this triumphant storyline, as will be noted later, but it reflects the dominant discourse of the document as a whole which underpins the proposals that emerge from it.

In this section of the overview, it will be helpful to compare and contrast Britain's Promise to Remember with two earlier texts, written in 1961 and 1998 respectively. They were produced for different purposes inside and outside the public domain - the first as internal government correspondence in relation to a wider media debate at the time of the Eichmann Trial, and the second as an educational tool at the end of the twentieth century when Holocaust consciousness and activism was growing in Britain. But all three can be located in the official sphere, produced either by the state or by institutions closely linked to it. Covering 55 years of postwar British history and confrontation with the memory of the Second World War and Nazism, they inevitably reveal both change and continuity, emphases and absences. What is perhaps more surprising is that alongside the constants (all relating to the mythology of Britain alone and the nation's self-image of decency, fairness, and tolerance), silences have grown (despite critical knowledge to the contrary) and are most pronounced in the most recent text, Britain's Promise to Remember.

There is not space here to cover in any detail what happened between the immediate postwar period and the Eichmann Trial in terms of British confrontations with the Holocaust. Recently, echoing work on America, there has been a reassessment of the alleged silence in Britain on the Holocaust from the late 1940s through to the early 1960s. At the forefront of this revisionism was the late David Cesarani, who in 2012 "challenged the notion that little was published in the way of memoirs, that historical research was both sporadic and patchy, and the subject barely figured in films or other mass media."49

There certainly were books published in Britain from the late 1940s through the 1950s that dealt with what would later be called the Holocaust, but it must be suggested that the wider engagement with them, and gaps that continued, also need to be acknowledged. For example, while Cesarani uses Lord Liverpool's best-selling Scourge of the Swastika: A Short History of Nazi War Crimes (1954) as an indication of the continuing interest in the subject matter, its publishers actually defended it on the grounds that they felt that "the horrors of Buchenwald and Auschwitz, which were so close to us ten years ago, have been too easily forgotten." ${ }^{50}$ A year earlier, the first history of the Holocaust written by a British author, Gerald Reitlinger's The Final Solution, was, according to one reviewer, "needed as a record of what has already become blurred in many minds." 51

The marketing history of two commercially successful autobiographies from the 1950s provides an indication that while the persecution of the Jews was not neglected, nor was it at the forefront of what publishers believed was demanded by the British public. The first was Ida Cook's We Followed Our Stars (1950), which came out of the romantic publishers, Mills \& Boon. As the title suggests, the focus was on how the author (and her sister, Louise) forged a close relationship with leading operatic singers of the interwar period in America and the continent, including Lita Galli-Curci, Maria Callas, and many others. The sisters' work helping Jews escape Germany during the 1930s was mentioned, but was not the focus of Ida Cook's memoir in its original form. ${ }^{52}$ In later editions, 
however, the emphasis was shifted to the Cooks' refugee work, with more material added on this theme and the title changed to Safe Passage to reflect their sustained efforts to get Jews out of Greater Germany. Indeed, it was given the subtitle "The Remarkable True Story of Two British Sisters Who Rescued Jews from the Nazis" in the 2016 version. Its latest cover emphasizes how they had "the unshakeable courage to save hundreds of Jews from Hitler's death camps [sic]... Safe Passage is a moving testimony to two women who risked everything to save others and help them rebuild their lives in freedom." ${ }^{53}$ In 2010, the Cook sisters were among the first to be awarded (posthumously in their case) the British medal "Heroes of the Holocaust," which no doubt prompted the republishing of Ida's memoir. ${ }^{54}$

Another posthumous recipient of this medal was Charles Coward, whose semi-fictional auto/biography, The Password is Courage (1956), went through a similar shift in focus, though in this case from prisoner of war escape narrative to one which its cover exclaimed was the story of "The Man Who Broke Into Auschwitz." Coward was transferred to the Auschwitz complex as a prisoner of war, working in the Monowitz camp from late 1943 alongside up to 1400 other British and Commonwealth soldiers in camp E715. The Password is Courage, however, romanticized his alleged work helping the Jewish inmates. This was not highlighted in earlier versions of the book, nor in the film of the same name released in 1962, which was a Hollywood precursor of The Great Escape, which came out a year later. While documentaries such as "This is Your Life," featuring both Ida Cook and Charles Coward, did focus on their work helping Jews (though at the same time marginalizing the voice of the victims), it remains that the original publications during the 1950s did not. ${ }^{56}$

But one particular area that remained ignored from the late 1940s onwards was the British government's role in rescuing Jews during the Nazi era. The Eichmann Trial brought this back into focus and in 1961 the Cabinet found itself under pressure to produce a White Paper on the subject of "Aid to the Jews in German-Occupied Europe during the War." This was not a new topic. During the war, activists such as Eleanor Rathbone, Victor Gollancz, and James Parkes had campaigned on behalf of European Jewry and criticized the British government for inaction. All three believed that Britain's reputation was at stake. ${ }^{57}$ Gollancz, for example, in Let My People Go, first published in January 1943, recognized the importance of what would later be labeled "British values":

Amid the peace, today, of the Berkshire countryside, it is difficult not to feel that there is something about Britain ... with its long record of democracy ... or whether it be that peculiar combination of gentleness and unsentimentality which is characteristic of her people.

Gollancz warned with regard to the rescuing of Jews faced with mass murder that "history does not forgive lost opportunities." 58 Two and a half years later, as the war in Europe came to an end, Gollancz reflected on the failed opportunities to save the Jews: it was a "bitter memory" as he recalled the public demands that the British government had ignored when he wrote Let My People Go. ${ }^{59}$

The work of these activists, however, was quickly forgotten in the postwar years. The only prominent reference to the British government and the Holocaust came from Zionists fighting against immigration restrictions on Jews trying to get to Palestine after 1945. This was a war of propaganda on both sides, with those on board ships such as 
Exodus 1947 quick to remind the world that, "When the white smoke of our cremating people rose in a protest to the very dome of heaven through weeks and months there was not a single British plane which sought to bomb the scenes of horror." 60

Fearing the impact of such propaganda and that coming from America, in 1946 the Foreign Office produced an alternative war narrative for consumption abroad. In the context of boats carrying Jewish survivors being turned away from Palestine by the British Navy, the British government's version had, in contrast, limited emotional resonance:

No country in the world has been a better or more consistent friend of the Jewish people than Britain. Wherever the Jews were persecuted the voice of Britain was lifted in protest and, wherever possible, action was taken to mitigate their lot ... In Britain there are no programs $[s i c]$ : Jews enjoy all the rights of civil liberty.

It added that a "large body of refugees from Nazi barbarism were received in this country. Even during the war." In fact, very few Jews were able to reach Britain after September 1939, due mainly to all pre-war visas being canceled by the Home Office. The claim that 200,000 refugees were allowed into Britain, a "large proportion of them Jews," was also a distortion (80,000 is the highest estimate), but it was deemed necessary with the attacks being launched on Britain's reputation. In desperation, the Foreign Office claimed that British soldiers and civilians were being "the victims of outrage more worthy of Nazis than of the Jewish victims of Nazis."61

After the debacle of Britain's exit from Palestine in 1948, it is hardly surprising that at either a state or a public level (including within British Jewry, which had been accused of dual loyalty and was subject to riots in August 1947), few would want to recall the help that was or was not given to the Jews during the war. What prompted Cabinet concern in 1961 were the very public controversies emerging from the Eichmann Trial, especially that relating to Joel Brand and possible negotiations between the Nazis and the Allies for Jewish lives, or "goods for blood" in 1944 when Hungarian Jewry was being deported en masse to Auschwitz. For a brief period, this was a matter of great interest and critical engagement in the British and world media.

Hurried research was carried out, which the government was anxious not to put in the public domain. Eventually, the combined forces of the Foreign Office and Cabinet Office managed to calm the interest. Bland responses were given to parliamentary questions on this issue, which soon dropped from general interest. Revealing the tendency towards selfcongratulation that has never really disappeared, and is unlikely to in the foreseeable future (given Britain's unique and untarnished - in its own mind - relationship to the Second World War), the Cabinet concluded that "the attitude of His Majesty's Government towards the problem of the Jews in Europe had in fact been as favourable as possible." 62 A tame question in the House of Commons by Labour MP Arthur Henderson was easily answered by Harold Macmillan, who confirmed that the government had not been "indifferent to the tragic fate which overcame the Jews in Central Europe."63

Behind the scenes, Whitehall librarians continued the process of finding relevant documentation lest public pressure demand further details. One area that the politicians felt was potentially sensitive were the requests in 1944 to bomb both the railway lines leading to Auschwitz and the camp itself. To the relief of the senior civil servants and ministers, parliamentary concern quickly died down and it was noted that the "British press 
ha[d] apparently lost interest." By August 1961, only the Israeli press were still asking whether a detailed White Paper on the British government and Jews in Nazi-occupied Europe would be issued based on contemporary documents. What could have been a moment of self-reflection was soon turned into an exercise in self-confirmation and it was emphasized that no serious opportunities had been rejected without serious consideration. Macmillan concluded that he was "absolutely satisfied that everything possible was done" and

the tragedy is that our efforts were to such little avail and that our constant appeals and warnings fell upon deaf ears. I am sure ... that we could have done no more than we did and that, when the time comes for the full publication of the records of the period, it will be shown that our concern for the fate of the Jews under Nazi domination was both sincere and constructive.

Internally there was only a small element of doubt about this narrative. A Cabinet official wondered if the phrase "absolutely satisfied" would stand scrutiny, especially that "over [the requests to bomb] Auschwitz [which] may be open to criticism."

The general theme, which revived the official line during the war and predicted the revisionist historiography of the 1990s - most prominently articulated by William Rubinstein - was that "His Majesty's Government repeatedly placed on record their detestation of the Nazi atrocities and determination to bring those responsible to book. They regarded the winning of the war ... as the surest and quickest way of rescuing Hitler's Jewish victims." Anticipating criticism over its restriction of Jewish immigration to Palestine to the limits of the 1939 White Paper, it emphasized also that the same considerations were in place and it governed "their policy in regard to the Middle East as a war base [and] the maintenance of law and order in Palestine." 65

There was no momentum, therefore, to encourage a more critical perspective. Britain experienced only minor ripples of the often polemical debate accusing the American government of indifference and indeed antipathy towards the Jewish plight that emerged in the 1960s. Andrew Sharfs work on the British press and the Jews, published in 1964, was one work perhaps indirectly influenced by the Eichmann Trial (Sharf was based at Bar Ilan University), but it was largely on its own and reflected more of the Zionist critique from the 1940s. ${ }^{66}$ Britain, in this respect, would remain several decades behind, and when the issue did emerge it was in a more restrained way and less newsworthy. Even so, Macmillan's confidence about Britain's reputation when the records were released was misplaced. The work of Bernard Wasserstein (1979) and Louise London (2000) was to present a very different story of the British government doing all it could to help. ${ }^{67}$

The official response - whether in the war itself, immediately after it, or as late as 1961 remained the same. All that could have been done was done, and Britain's record was untarnished and indeed commendable in terms of the refugees who were allowed entry. No wonder, then, that in the 2016 survey there is little awareness of any debate about its role and even the assumption from over one third of the sample that somehow Britain actually fought the war to save the Jews. It concludes from both its qualitative and quantitative evidence that it is "clearly demonstrated that many students did not have the necessary contextual knowledge to accurately explain Britain's response to the Holocaust." 68

In the mid-1960s, official British understanding and knowledge of the Holocaust became a practical rather than a general theoretical matter about its war reputation. 
Coming out of complex diplomacy and agreements from the 1950s, the West German government gave $£ 1$ million to compensate British victims of Nazi persecution. Britain was the second last country to receive such compensation, which reflected lengthy arguments about who was to be included under the scheme. ${ }^{69}$ It was implemented by the British government and the definitional problems did not go away. The first was who was British (problematic for those of dual nationality or who had been naturalized after the war), and the second and larger was what was, and was not, "Nazi persecution." A very basic and crude reading was provided, limited solely to the concentration camps. Even then, British victims had to be in the camp proper and not in prison cells within them. As one failed applicant who had a brutal experience in a Nazi internment camp was told, the hardships he had experienced were "different in kind from the tortures and gas chambers which formed the essential part of concentration camp treatment."70

The episode revealed the lack of Foreign Office knowledge of Nazi persecution - the responsible civil servants were given a crash course in the subject by reading popular books such as Eugen Kogon's The Theory and Practice of Hell and Gerald Reitlinger's The Final Solution. ${ }^{71}$ Furthermore, what could have been a moment to confront the Holocaust became yet again another moment to reflect on a British war narrative. The greatest controversy concerned those airmen who had been involved in the "Great Escape" who ended up in Sachsenhausen. Initially denied compensation because it was deemed they were not full inmates of the camp and "only" in a prison section of it, a public and parliamentary campaign ensured after several years of heated debate that they would be given awards under the scheme. ${ }^{72}$ As Susanna Schrafstetter concludes, in the 1960s, "the British media ... perceived compensation for British victims of Nazism largely as compensation for British war heroes."73

The tendency towards conformity is evident at this time in the narrative provided by Harold Osmond Le Druillenec. A former school teacher from St Helier, Jersey, he and his family were deported from the Channel Islands by the Nazis in June 1944 having helped a Russian prisoner to escape and being in possession of a forbidden wireless set. From a prison near Rheims, Le Druillenec was transferred first to Neuengamme concentration camp and then around 5 April 1945 to Belsen. In 1964 he applied for compensation under the German scheme for the ill health he had subsequently experienced and was given one of the largest awards, totaling $£ 1835$. Yet having briefly outlined the desperate conditions of its last days as a concentration camp, including "rampant" cannibalism, Le Druillenec lapsed into classic war stoicism understatement mode, concluding that Belsen was "[a]ll in all a most unpleasant place." Using a cricketing metaphor, he made light of the severe and permanent physical and mental disabilities he had suffered, concluding that he had survived through luck and the ability to "live outside the crease." ${ }^{74}$ It contrasts markedly with his testimony to the Belsen Trial in September 1945, where, just out of hospital, he emphasized how impossible it was to communicate the horrors of the camp: "A night in those huts was something I think maybe a man like Dante might describe but I simply cannot put into words." He did try, however, at the end of his evidence, frustrated perhaps at the crassness of the questioning from the British military prosecutors and cross-examiners: "I think I can fairly describe Belsen as probably the foulest and vilest spot that ever soiled the surface of this earth."75 Contrasting Le Druillenec's testimony from 1945 and 1964, it is apparent that the horrors of Belsen had become domesticated. 


\section{IV}

Slowly, from the 1970s through to the 1990s, and partly through the American and continental examples, greater interest in the Holocaust emerged in Britain, especially in the last decade of the twentieth century when greater emphasis was being placed on multiculturalism and anti-racism. The Holocaust was placed on the National Curriculum, there was legislation enabling the prosecution of Nazi war criminals who came to Britain after the war, and the Imperial War Museum, long averse to incorporating the subject, developed a permanent exhibition focusing almost totally on the Jewish victims and which, ironically, was larger than what it had devoted to the Second World War. ${ }^{76}$ As a reflection of this greater engagement, the Holocaust Educational Trust (HET), which had been involved politically in a range of matters beyond the pedagogical, produced in 1998 a pamphlet entitled Britain and the Holocaust. ${ }^{77}$

There is continuity present here in that the author of this educational resource, David Cesarani, was from the start to his untimely death in 2015 a key player in the Prime Minister's Holocaust Commission. In the earlier HET document, there is a striving for balance and fairness. It possesses, however, a far more critical edge, reflecting perhaps that the Holocaust was yet in 1998 to be part of the nation's story and that forceful memory work was still required to ensure this was achieved. The pamphlet thus starts by declaring: "The Holocaust is a part of British History." That bold statement is then followed by a commitment to ambivalence and ambiguity so absent in the 2015 report:

Yet the story of Britain's involvement with the Jewish people during the Nazi period is little known and poorly understood. It is a troubled episode that combines humanitarianism and xenophobia, heroism and pettiness, achievement and failure. ${ }^{78}$

Only in the first sentence is there (partial) commonality with Britain's Promise to Remember. In a sub-section of the later document, labeled "The Holocaust as part of British history," it is repeated that "[e]nsuring the memory and the lessons of the Holocaust are never forgotten lies at the heart of Britain's values as a nation." Curious, in the light of this assumption, is the more reflective acknowledgment: "But the full story is not well known." B9 Britain has thus imbued the message of the Holocaust without knowledge of the event itself or the country's relationship to it.

In contrast, Cesarani's pamphlet is carefully written to show the complexity of British responses: Britain opened up its borders to refugees during the 1930s, but within a restrictionist mentality. Moreover, the closing of the doors to Palestine is freely acknowledged; the limitations of its contribution to the Evian conference in July 1938 are made clear, and the Kindertransport is described as "qualified generosity ... the children were received on a temporary basis only and their parents were excluded because they might have competed on the job market." ${ }^{80}$ In contrast, the Kindertransport is a totally praiseworthy scheme in Britain's Promise to Remember. ${ }^{81}$

It is only recently that the Kindertransport has become celebrated in British society and politics, used, for example, to criticize refugee policy and the failure to bring Syrian children to Britain or, alternatively, to defend the decision as the comparison between the two forced migrations is rejected as inappropriate. ${ }^{82}$ As late as 2002 , Ken Livingstone, then mayor of London, speaking at a Holocaust commemoration at Liverpool Street station (later the site of two rival memorials to the Kindertransport), stated that, "Until today, I 
did not know that Jewish children had escaped to London before the Second World War." 83 Since then, this child refugee movement has become mythologized to the extent that the problems associated with it (not just the separation from parents but the physical, economic, sexual, and mental abuse suffered by some of the children in Britain) have become totally obscured. The distortion of its importance is reflected in the evidence gathered in the Centre for Holocaust Education report, with students asking whether "the Holocaust was a train that took Jews out of Germany to help them?" or stating, "The Holocaust was when Jews got killed and children had to go to kindertransport." ${ }^{\prime 4}$ Taking the Kindertransport out of context leads to a loss of proportion and confusion over chronology.

In Cesarani's narrative, during the war, the Allied Declaration of December 1942 is highlighted but so is official skepticism over atrocity stories, the turning away of boats reaching Palestine, including the Patria, the failure of the Bermuda conference, and British inaction over Hungary in 1944, including the Brand episode, and the refusal to bomb the railway lines to Auschwitz. ${ }^{85}$ Dealing with the last months of conflict and the postwar period, the liberation of Belsen, so prominent in Britain's Promise to Remember (it is referenced five times), is also featured, but again there is nuance in David Cesarani's text. Both highlight Richard Dimbleby's iconic BBC radio broadcast, but only Cesarani's pamphlet acknowledges that it never explicitly referenced the Jews. ${ }^{86}$ As is now known, Dimbleby recorded two versions and the one that included the Jews was never broadcast at the time. ${ }^{87}$

But perhaps what differentiates the 1998 document from that in 2015 is what is not in the latter. There are two pages in Britain and the Holocaust devoted to the Channel Islands and the fate of the small Jewish population there. Cesarani emphasizes how official reports of collaboration from the Islanders and their officials were suppressed for 40 years. Even more provocatively, but echoing the thoughts of MI5 and others from 1945, he concludes that,

Although huge differences exist between the Channel Islands and mainland Britain, what happened in the Channel Islands can be seen as an indicator as to how the British would have responded in the event of a successful German invasion and occupation. Sadly, the evidence suggests that there would have been as many collaborators and 'quislings' as in occupied Europe. The Jews would have faced the usual forms of persecution and would have received little help. ${ }^{88}$

\section{V}

It is revealing that Britain's Promise to Remember does not mention the Channel Islands once. Would, however, $£ 100$ million of tax payer and philanthropic contributions be made to a project entitled Britain's Promise to Forget? That the state refuses to contribute to the $£ 1$ million project to create a national memorial to slavery in London suggests not. As black historian and campaigner David Olusoga notes, "Given the scale of Britain's involvement and the enormous profits generated from the trade, the creation of a single memorial to the victims of that system in a London rose garden seems a fairly modest demand." ${ }^{89}$ However modest, it remains that selective amnesia of truly difficult, challenging history closer to home has its price, and that is of silencing more marginal voices. ${ }^{90}$

To conclude: the message of the Prime Minister's Holocaust Commission Report, for all its resources, takes scholarship and memory work back at least to 1961. Its message with 
regard to the nation's own role is summarized by a quote from Ian Austin MP, the enhanced font size emphasizing its importance within the document:

Whilst Britain could have done more, no one can deny that when other European countries were rounding up their Jews and putting them on trains to concentration camps, Britain provided a safe haven for tens of thousands of refugees. In 1941, with Europe overrun and America not yet in the war, just one country - Britain - soldiered on, against all odds, fighting not just for our freedom, but for the world's liberty, too.

Austin concludes that he "believes this period defines Britain and what it is to be British. It is Britain's unique response to the Holocaust and its unique role in the war that gives us the right to claim a particular attachment to the values of democracy, equality, freedom, fairness and tolerance." ${ }^{\text {"1 }}$ To sum up the Commission Report: a uniquely tolerant nation responds with unique decency and fairness to a uniquely horrible (and foreign perpetrated) crime. This is not so much memory work as memory comfort. And forgetting, as Paul Ricoeur argues, ultimately does not lead to "carefreeness." Complacency "with the wearing away of time" would "simply add a gracious note to the work of memory and the work of mourning. For it would not be work at all." ${ }^{92}$ As this overview has emphasized, however, at all times the dominant (and often state-sponsored) narrative has been challenged. Indeed, the philosophy behind the 2016 UCL survey itself reflects a nuanced, reflexive, and independent approach that has evolved since the late twentieth century and runs totally counter to the crude certainties and national self-aggrandisement of the Holocaust Commission Report. At a time of increasing ethnic and racial tension at a global level, and the worst refugee crisis since the Second World War, critical perspectives are more than ever required in the dialogue between "then" and "now."

\section{Notes}

1. Freeman, "Boris is Blond."

2. Johnson, interviewed in the Sunday Telegraph, 15 May 2016.

3. Freeman, "Boris is Blond." On the Vel'd'Hiv roundup of May 1941 and more generally, see Poznanski, Jews in France during World War II.

4. Interview in the Spectator, 13 July 1990. See Guardian, 13 July 1990 for details of the political fallout of these comments.

5. In a BBC Radio London interview, 28 April 2016, reported in Evening Standard, 28 April 2016.

6. Ibid.

7. Livingstone, reported in the Guardian, 30 April 2016; Brenner, Zionism in the Age of the Dictators.

8. Freeman, "Boris is Blond."

9. Freeman, "Nobody Wants to Be the Bad Guy."

10. Johnson, The Churchill Factor.

11. Spectator, 13 July 1990.

12. Foster et al., What Do Students Know.

13. Ibid., 2.

14. For wider exploration of this relationship, see Bunting, "Britain and the Holocaust."

15. Celinscak, Distance from the Belsen Heap, xv.

16. On the liberation, see Reilly, Belsen: The Liberation of a Concentration Camp; Shepherd, After Daybreak; and Celinscak, Distance from the Belsen Heap. On its memory, see Reilly et al., Belsen in History and Memory; and Bardgett and Cesarani, Belsen 1945.

17. Churchill, in Hansard HC vol. 410, cols. 389-90, 19 April 1945. 
18. Ibid., and Chuter Ede diaries, 19 and 20 April 1945 in MS 59700, British Library.

19. Buchenwald: The Report of a Parliamentary Delegation, 3,7.

20. Eisenhower, letter to George Marshall, text reproduced on the United States Holocaust Memorial Museum website, "Holocaust Encyclopedia," under Ohrsdruf. https://www.ushmm.org/. Accessed 22 May 2016.

21. Haggith, "The 1945 Documentary," 181-97. See also National Archives, INF 1/636.

22. Sontag, On Photography, 19-20.

23. Richmond, "Diary." Richmond was in the circle of the Regal Cinema, High Street, Sidcup, Kent.

24. Sillitoe, Memoirs of a Philo-Semite, based on the Parkes Centenary Lecture, 'Jewish Influences on My Writing,' 6 March 1996.

25. Frederic Raphael, “The Worst of Times,” Independent, 2 March 1993.

26. Mass-Observation Archive, The Keep (hereafter M-O A), D5270, 21 April 1945.

27. M-O A, File Report 2248 on German atrocities.

28. "The Edge of the Ceiling," in Garner, The Voice That Thunders. For comment on these memories for one born a generation later, see the chapter by writer Ali Smith in Wagner, First Light.

29. “One Pair of Eyes: All Systems Go - Alan Garner," BBC, 1972, director Lawrence Moore, in BFI DVD, Red Shift with notes by Paul Vanezis.

30. Frank Davey, "Children from Belsen Have London Feast," News Chronicle, 6 December 1945. See similarly, "Children from Belsen," Southern Daily Echo, 31 October 1945.

31. "Belsen Orphans in England," Jewish Chronicle, 2 November 1945.

32. Panter-Downes, "A Quiet Life in Hampshire."

33. Ibid., and see also Panter-Downes, "In an English Country Mansion Live the Children Who Don't Trust Anybody," Sunday Dispatch, 7 April 1946.

34. Foster et al., What Do Students Know, 195.

35. "Mockery of Belsen," People, 7 October 1945.

36. H.H. Prestige, minute 30 October 1945, National Archives, HO 213/618.

37. T.H. Tilling, letter to Miss Markham, 25 March 1946, National Archives, HO 213/695.

38. Ibid.

39. Sunday Express, 6 January 1946.

40. Tilling to Markham, 25 March 1946, National Archives, HO 213/695.

41. A. Judge, memorandum, 21 May 1946, in National Archives, HO 213/695.

42. The files on this murder are closed until 2022 and 2044 respectively. See National Archives, ASSI 13/124 and ASS1 88/20.

43. Paytress, Bolan, chapter 1.

44. Britain's Promise to Remember.

45. David Cameron, ITV News, 30 July 2015. For favorable comment, see Daily Mail, 31 July 2015, and for Harriet Harman's critique, see the Guardian, 31 July 2015.

46. Britain's Promise to Remember, 5 reported by Mick Davis from the first meeting of the Holocaust Commission in January 2014.

47. Ibid., 9.

48. Ibid.

49. Cesarani, "How Post-War Britain Reflected," 101. This article builds on studies such as Baron, "The Holocaust and American Public Memory."

50. Cesarani, "How Post-War Britain Reflected," 118; Lord Russell of Liverpool, Scourge of the Swastika. The publisher's comments are from the 1958 edition.

51. Reitlinger, The Final Solution. Review in the Manchester Guardian. For a summary of the reviews, see Wiener Library Bulletin, May-August 1953.

52. Cook, We Followed Our Stars.

53. Cook, Safe Passage, foreword by Anne Sebba.

54. Smith, Heroes of the Holocaust, 69-84.

55. Castle, The Password is Courage. See also Kushner, "Loose Connections?" 56-7. 
56. James Jordan is carrying out extensive research on the BBC and the Holocaust as part of wider work on the BBC and the Jews. "This Is Your Life" is an important element of this project. Ida Cook's program was broadcast on 11 March 1956 and Charles Coward's on 24 October 1960. See Jordan, "And the Trouble is Where to Begin," 90-114.

57. Rathbone, Rescue the Perishing; Gollancz, Let My People Go; James Parkes, "The Massacre of the Jews: Future Vengeance or Present Help?", January 1943, unpublished article in University of Southampton archives, MS 60/9/5/1.

58. Gollancz, Let My People Go, 32.

59. Gollancz, "Nowhere to Lay Their Heads", 1.

60. Broadcast from Exodus 1947, National Archives, CO 537/2400.

61. Memorandum, 11 August 1946, National Archives, CO 537/1797.

62. Cabinet meeting, 23 August 1961, CAB 21/5589.

63. Hansard HC vol. 642, cols. 202-3, 13 June 1961.

64. Macmillan draft letter to Henderson, June 1941, and Woods letter to Mason, 29 June 1961, CAB 21/5589.

65. G.F. Hiller draft memorandum, "Aid to Jews in German-occupied Europe During the War Years” (June/July 1961), in National Archives, CAB 21/5589. See also Rubinstein, The Myth of Rescue.

66. Sharf, The British Press.

67. Wasserstein, Britain and the Jews of Europe; London, Whitehall and the Jews.

68. Foster et al., What Do Students Know, 183, 208.

69. Schrafstetter, "Gentlemen, the Cheese Is All Gone!" 28.

70. I. Vair-Turnbull of the Foreign Office to W. Macpherson, 1 September 1964, National Archives, FO 950/1261.

71. See FCO 64/56.

72. This is summed up in National Archives, PREM 13/2274.

73. Schrafstetter, "Gentlemen, the Cheese Is All Gone!" 42.

74. National Archives, FO 950/1100.

75. Evidence given on the fourth day of the trial, 20 September 1945. For transcripts, see http:// www.bergenbelsen.co.uk/pages/TrialTranscript/Trial_Contents.html. Accessed 7 June 2016. See also National Archives, WO 235/24 for his evidence.

76. For a thorough and thoughtful overview, see Pearce, Holocaust Consciousness in Contemporary Britain.

77. Cesarani, Britain and the Holocaust.

78. Ibid., 2.

79. Britain's Promise to Remember, 21.

80. Cesarani, Britain and the Holocaust, passim.

81. Britain's Promise to Remember, 9.

82. See, for example, the debate on Channel 4 news, 4 May 2016, between former Kind, Helena Pick, and Conservative Sir Edward Leigh.

83. Jewish Chronicle, 1 February 2002.

84. Foster et al., What Do Students Know, 53-4.

85. Cesarani, Britain and the Holocaust, 11-14.

86. Britain's Promise to Remember, 9; Cesarani, Britain and the Holocaust, 16.

87. Petersen, "How British Television Inserted the Holocaust into Britain's War Memory."

88. Cesarani, Britain and the Holocaust, 15-16. For MI5 reports, see National Archives, KV 4/78 and HO 45/22399.

89. Olusoga, "Why Has a Memorial."

90. This reality challenges the optimism, however well meaning, in Rothberg's Multidirectional Memory.

91. Britain's Promise to Remember, 23.

92. Ricoeur, Memory, History, Forgetting, 505. 


\section{Disclosure statement}

No potential conflict of interest was reported by the author.

\section{Notes on contributor}

Tony Kushner is Marcus Sieff Professor of the History of Jewish/Non-Jewish Relations at the University of Southampton. He is the author of eight monographs, and a leading authority on the history of Holocaust history and memory in Britain. He is co-editor of the journal Patterns of Prejudice and deputy editor of Jewish Culture and History.

\section{Bibliography}

\section{Archives}

\section{British Library.}

Chuter Ede diaries, 19 and 20 April 1945 in MS 59700.

Mass-Observation Archive, The Keep.

Diaries, Second World War.

File Reports, Second World War.

National Archives.

CAB 21/5589.

CO 537/1797; 537/2400.

FCO 64/56.

FO 950/1100, 1261.

HO 45/22399; HO 213/618; HO 213/695.

INF $1 / 636$.

KV $4 / 78$.

PREM 13/2274.

WO 235/24.

University of Southampton Archives.

James Parkes papers, MS 60/9/5/1.

\section{Publications}

Bardgett, Suzanne and David Cesarani, eds. Belsen 1945: New Historical Perspectives. London: Vallentine Mitchell, 2006.

Baron, Lawrence. "The Holocaust and American Public Memory, 1945-1960." Holocaust and Genocide Studies 17, no. 1 (2003), 62-88.

Brenner, Lenni. Zionism in the Age of the Dictators. London: Croom Helm, 1983.

Britain's Promise to Remember: The Prime Minister's Holocaust Commission Report. London: Cabinet Office, 2015.

Buchenwald: The Report of a Parliamentary Delegation. London: HMSO, CMd 6626, 1945.

Bunting, Aimee. "Britain and the Holocaust: Then and Now." unpublished PhD thesis, University of Southampton, 2006.

Castle, John. The Password is Courage. London: Corgi, 1956.

Celinscak, Mark. Distance from the Belsen Heap: Allied Forces and the Liberation of a Nazi Concentration Camp. Toronto: University of Toronto Press, 2015.

Cesarani, David. Britain and the Holocaust. London: Holocaust Educational Trust, 1998.

Cesarani, David. "How Post-War Britain Reflected on the Nazi Persecution and Mass Murder of Europe's Jews: A Reassessment of Early Responses." In Whatever Happened to British Jewish 
Studies?, edited by Tony Kushner and Hannah Ewence, 99-135. London: Vallentine Mitchell, 2012.

Channel 4 news, 4 May 2016.

Cook, Ida. We Followed Our Stars. London: Mills \& Boon, 1950.

Cook, Ida. Safe Passage. London: Harlequin, 2016.

Evening Standard, 28 April 2016.

Daily Mail, 31 July 2015.

Foster, Stuart, et al. What Do Students Know and Understand about the Holocaust? Evidence from English Secondary Schools. London: UCL Centre for Holocaust Education, 2016.

Freeman, Hadley. "Boris is Blond, Plays Stupid and Wants to Lead the Country. Remind You of Anyone?”, Guardian Weekend Magazine, 21 May 2016.

Freeman, Hadley. "Nobody Wants to Be the Bad Guy, but it's Time the Left Faced up to Antisemitism," Guardian Weekend Magazine, 7 May 2016.

Garner, Alan. The Voice That Thunders: Essays and Lectures. London: Harvill, 1997.

Gollancz, Victor. Let My People Go. London: Gollancz, 1943.

Gollancz, Victor. "Nowhere to Lay Their Heads": The Jewish Tragedy in Europe and Its Solution. London: Gollancz, 1945.

Guardian, 13 July 1990; 31 July 2015; 30 April 2016; 7 May 2016; 21 May 2016.

Haggith, Toby. "The 1945 Documentary German Concentration Camps Factual Survey and the 70th Anniversary of the Liberation of the Camps." The Holocaust in History and Memory 7 (2014), 181-97.

Hansard. HC vol. 410, 19 April 1945.

Hansard. HC vol. 642, 13 June 1961.

Independent, 2 March 1993.

ITV News, 30 July 2015.

Jewish Chronicle, 2 November 1945; 1 February 2002.

Johnson, Boris. The Churchill Factor: How One Man Made History. London: Hodder \& Stoughton, 2014.

Jordan, James. ““'And the Trouble Is Where to Begin to Spring Surprises on You. Perhaps a Place You Might Least Like to Remember." This Is Your Life and the BBC's Images of the Holocaust in the Twenty Years Before Holocaust." In Britain and the Holocaust: Remembering and Representing War and Genocide, edited by Caroline Sharples and Olaf Jensen, 259-74. Basingstoke: Palgrave Macmillan, 2013.

Eugen Kogan. The Theory and Practice of Hell. New York: Farrar, Straus, 1950.

Kushner, Tony. "Loose Connections? Britain and the 'Final Solution'." In Britain and the Holocaust: Remembering and Representing War and Genocide, edited by Caroline Sharples and Olaf Jensen, 51-67. Basingstoke: Palgrave Macmillan, 2013.

London, Louise. Whitehall and the Jews 1933-1948. Cambridge: Cambridge University Press, 2000.

Lord Russell of Liverpool. Scourge of the Swastika: A Short History of Nazi War Crimes. London: Cassell, 1954.

News Chronicle, 6 December 1945.

Observer, 4 October 2015.

"One Pair of Eyes: All Systems Go - Alan Garner," BBC 1972, director Lawrence Moore in BFI DVD, Red Shift with notes by Paul Vanezis.

Panter-Downes, Mollie. “A Quiet Life in Hampshire,” New Yorker, 2 March 1946.

Paytress, Mark. Bolan: The Rise and Fall of a 20th Century Superstar. London: Omnibus Press, 2009.

Pearce, Andy. Holocaust Consciousness in Contemporary Britain. New York: Routledge, 2014.

People, 7 October 1945.

Petersen, Judith. "How British Television Inserted the Holocaust into Britain's War Memory." Historical Journal of Film, Radio and Television 21, no. 3 (2001), 255-72.

Poznanski, Renee. Jews in France during World War II. Hanover, New Hampshire: Brandeis University Press, 2001.

Rathbone, Eleanor. Rescue the Perishing. London: National Committee for Rescue from Nazi Terror, 1943. 
Reilly, Joanne, et al., eds. Belsen in History and Memory. London: Frank Cass, 1997.

Reilly, Joanne. Belsen: The Liberation of a Concentration Camp. London: Routledge, 1998.

Reitlinger, Gerald. The Final Solution. London: Vallentine Mitchell, 1953.

Richmond, Colin. "Diary," London Review of Books, 13 February 1992.

Ricoeur, Paul. Memory, History, Forgetting. Chicago: University of Chicago Press, 2006.

Rothberg, Michael. Multidirectional Memory: Remembering the Holocaust in the Age of Decolonization. Stanford: Stanford University Press, 2009.

Rubinstein, W. D. The Myth of Rescue. London: Routledge, 1997.

Schrafstetter, Susanna. 'Gentlemen, the Cheese Is All Gone! British POWs, the 'Great Escape,' and the Anglo-German Agreement for Compensation to Victims of Nazism." Contemporary European History 17, no. 1 (2008), 23-43.

Sharf, Andrew. The British Press and Jews Under Nazi Rule. London: Oxford University Press, 1964. Shepherd, Ben. After Daybreak: The Liberation of Bergen-Belsen, 1945. London: Jonathan Cape, 2005.

Sillitoe, Alan. Memoirs of a Philo-Semite: Jewish Influences on My Writing. Southampton: University of Southampton, 1996.

Smith, Lyn. Heroes of the Holocaust: Ordinary Britons who Risked Their Lives to Make a Difference. London: Ebury Press, 2013.

Sontag, Susan. On Photography. Harmondsworth: Penguin, 1979.

Southern Daily Echo, 31 October 1945.

Spectator, 13 July 1990.

Sunday Dispatch, 7 April 1946.

Sunday Express, 6 January 1946.

Sunday Telegraph, 15 May 2016.

Wagner, Erica, ed. First Light: A Celebration of Alan Garner. London: Penguin, 2016.

Wasserstein, Bernard. Britain and the Jews of Europe 1939-1945. Oxford: Oxford University Press, 1979. 